\title{
Bactericidal activity of a monocytic cell line (THP-1) against common respiratory tract bacterial pathogens is depressed after infection with respiratory syncytial virus
}

\author{
M. W. RAZA, C. C. BLACKWELL, R. A. ELTON* and D. M. WEIR \\ Department of Medical Microbiology and *Medical Statistics Unit, University of Edinburgh, Teviot Place, \\ Edinburgh EH8 9AG
}

\begin{abstract}
Non-typable Haemophilus influenzae, Streptococcus pneumoniae, Moraxella catarrhalis and respiratory syncytial virus (RSV) are commonly isolated from patients during the course of chronic obstructive pulmonary disease (COPD). Earlier studies found that virus infection enhanced binding of bacterial respiratory pathogens to epithelial cells in vitro. The objective of the present study was to assess the effect of RSV infection of a human monocytic cell line on bactericidal activity and cytokine production in response to these bacterial respiratory pathogens. The effect of RSV infection on binding, uptake and intracellular killing of bacteria by a human monocytic leukaemia cell line, THP-1, was assessed. Cell culture supernates were examined with a mouse fibroblast cell assay for tumour necrosis factor- $\boldsymbol{\alpha}$ (TNF- $\boldsymbol{\alpha}$ ) bioactivity. Expression of CD14, CD11a, CD18, CD15 and CD29 on uninfected and RSV-infected THP-1 cells was assessed by flow cytometry in relation to differences in bacterial binding. RSV infection of THP-1 cells significantly decreased their ability to bind and kill bacteria. Compared with uninfected cells, fewer bacteria bound to RSV-infected THP-1 cells and the surface antigens that have been reported to bind bacteria were expressed at lower levels on RSV-infected cells. RSV-infected cells incubated with bacteria exhibited less TNF- $\boldsymbol{\alpha}$ bioactivity than uninfected cell incubated with bacteria. The results elucidate some of the mechanisms involved in the increased susceptibility of virus-infected patients to secondary bacterial infection. Reduced bacterial killing by virus-infected monocytes might contribute to reduced clearance of bacteria from the respiratory tract and damage elicited by the bacteria or cytokine response in COPD patients.
\end{abstract}

\section{Introduction}

Chronic obstructive pulmonary disease (COPD), which includes chronic bronchitis and emphysema, is an important cause of ill health in older age groups. Whilst cigarette smoking is a major risk factor for the condition [1], the precise role of microbial infections in its development and progress has yet to be elucidated $[2,3]$.

Non-typable Haemophilus influenzae, Streptococcus pneumoniae and Moraxella catarrhalis are common bacterial species isolated from patients during episodes of exacerbation in the course of COPD and asthma [4-7]. Respiratory syncytial virus (RSV) is an

Received 19 A pril 1999, accepted 11 August 1999.

Corresponding author: $\mathrm{Dr}$ M. W. Raza important viral pathogen in older groups, because complete immunity does not follow RSV disease and re-infections are not uncommon [8]. Fagon and Chastre [9] reviewed studies comparing the tracheobronchial microflora of patients during acute exacerbations and stable periods in the course of COPD; significant differences in isolation rates in these studies were found only for viruses (influenza virus and RSV). These studies did not measure the bacterial flora of the respiratory tract or the effect of acute viral infections on inflammation due to the resident flora. Infection of epithelial cells with RSV increased binding of respiratory bacterial pathogens [10-12]. Patients with RSV infections showed a significant rise of antibodies to $H$. influenzae, S. pneumoniae and $M$. catarrhalis [13].

Viral infections might also alter the bactericidal 
mechanisms in the respiratory tract. Alveolar macrophages play an important role in killing and inhibition of replication of inhaled micro-organisms and in inflammation in the respiratory tract due to these agents. A human monocytic leukaemia cell line, THP-1 [14], possesses the properties of alveolar macrophages [15] and was adopted as an appropriate model to study interaction between RSV and bacterial species isolated from patients with COPD.

The first objective of this study was to examine the effect of RSV infection of THP-1 cells on binding, ingestion and intracellular survival of strains of $\mathrm{H}$. influenzae, S. pneumoniae and M. catarrhalis. Surface antigens on monocytes, CD14, CD11a, CD18, CD15 and CD29 - some of which act as bacterial receptors $[16,17]$ - can be modified during inflammation [18]. RSV infection suppressed the expression of LFA-1 $(C D 11 a+C D 18)$ on human monocytes [19]. The second objective of this study was to examine the changes in the cell-surface antigens associated with RSV infection in relation to the ability of monocytes to bind and ingest bacterial isolates. Tumour necrosis factor- $\alpha$ (TNF- $\alpha$ ) plays a role in defence against viral $[20,21]$ and bacterial infection $[22,23]$, but its release also results in inflammation in the respiratory tract and contributes to the systemic symptoms in patients with COPD $[24,25]$. The third objective was to examine the effect of RSV infection and different strains of bacteria, or both, on TNF- $\alpha$ release from THP-1 cells.

\section{$M$ aterials and methods}

\section{RSV}

The Edinburgh strain of RSV (subgroup A) was harvested from HEp-2 cells maintained in maintenance medium (M M) which consisted of RPM I-1640 supplemented with fetal calf serum (FCS) $1 \%$ and $2 \mathrm{mM} \mathrm{L-}$ glutamine, penicillin $100 \mathrm{IU} / \mathrm{ml}$ and streptomycin $200 \mu \mathrm{g} / \mathrm{ml}$. The suspension was tested by immunofluorescence for presence of mycoplasma. The concentration was adjusted to $2 \times 10^{6}$ plaque forming units $/ \mathrm{ml}[10]$.

\section{Bacteria}

There were two isolates each of nontypable $H$. influenzae (HII and HI2), M. catarrhalis ( $\mathrm{MCl}$ and MC2) and S. pneumoniae (types 3 and 6 ) from patients with exacerbation of COPD obtained from the Clinical Bacteriology Laboratory of the department. $\mathrm{H}$. influenzae and pneumococcal isolates were sensitive to ampicillin. M. catarrhalis strain MCl grew on $\mathrm{New}$ York City medium with antibiotics selective for the pathogenic neisseria: lincomycin $1 \mu \mathrm{g} / \mathrm{ml}$, colistin $6 \mu \mathrm{g} / \mathrm{ml}$, amphotericin $1 \mu \mathrm{g} / \mathrm{ml}$ and trimethoprim lactate $6.5 \mu \mathrm{g} / \mathrm{ml}$. M. catarrhalis MC2 did not grow on this medium. Overnight growths of $\mathrm{H}$. influenzae and $M$. catarrhalis on boiled blood agar and $S$. pneumoniae on blood agar were collected in phosphate-buffered saline (PBS) and washed twice by centrifugation at $2500 \mathrm{~g}$ for $10 \mathrm{~min}$. Heavy bacterial suspensions in $M M$ without antibiotics were stored in small volumes at $-20^{\circ} \mathrm{C}$ for up to 3 months for use in the assays. Concentrations of live bacteria in the frozen samples were determined by plating triplicate samples $(5 \mu \mathrm{l})$ of appropriate dilutions in PBS on appropriate media for determination of colony forming units (cfu) after overnight growth in air with $\mathrm{CO}_{2} 5 \%$ at $37^{\circ} \mathrm{C}$.

\section{Ethidium bromide-labelling of bacteria}

The bacterial suspensions were washed with PBS and fixed with buffered paraformaldehyde (Sigma) $1 \%$ for $30 \mathrm{~min}$ in a water bath at $37^{\circ} \mathrm{C}$. The bacteria were washed twice with PBS and incubated with ethidium bromide (EB; Sigma) $50 \mu \mathrm{g} / \mathrm{ml}$ for $20 \mathrm{~min}$ in a water bath at $37^{\circ} \mathrm{C}$. The bacteria were washed twice and the total count was adjusted to $4 \times 10^{8} / \mathrm{ml}$ in PBS by direct microscopy. The labelled bacteria were held in small volumes at $-20^{\circ} \mathrm{C}$ for up to 3 months.

\section{THP-1 cells}

THP-1 cells (European Collection of A nimal Cells Cultures, Salisbury, Wilts) were cultured in growth medium (GM) which contained the same components as MM except for the higher concentration of FCS $(10 \%)$ and the presence of mercapto-ethanol $\left(2 \times 10^{-5} \mathrm{M}\right)$. The suspension was tested as described earlier for presence of mycoplasma. The cells were kept at $37^{\circ} \mathrm{C}$ in $\mathrm{CO}_{2} 5 \%$. Fresh cultures of cells were infected with RSV at a multiplicity of infection of 2 . Overnight cultures of uninfected and RSV-infected cells were washed with MM without antibiotics by centrifugation at $300 \mathrm{~g}$ for $7 \mathrm{~min}$ and the counts were adjusted to $1 \times 10^{6} / \mathrm{ml}$ in this medium by microscopy, for use in the experiments.

The proportions of monocytes infected with RSV in the samples were determined by flow cytometry by indirect immunofluorescence. The proportions were compared in one experiment with a mouse monoclonal antibody $(M A b)$ to a viral surface glycoprotein $G$ [10] or a convalescent serum from a patient with RSV infection previously absorbed with THP-1 cells and appropriately diluted in PBS. FITC-conjugated anti-mouse immunoglobulin or anti-human immunoglobulin antibodies (Sigma) were used to detect primary antibodies on cells. The convalescent serum was used to detect RSVinfected cells in subsequent experiments. The viability of RSV-infected and uninfected THP-1 cells was determined by trypan blue exclusion.

\section{Bacterial binding}

Uninfected and RSV-infected THP-1 cells $\left(2 \times 10^{5}\right)$ in capped plastic tubes were mixed with EB-labelled bacteria to provide a ratio of 10 bacteria per cell and 
incubated at $37^{\circ} \mathrm{C}$ in an orbital incubator $(40 \mathrm{rpm})$. Samples were removed after incubation for 0 or $30 \mathrm{~min}$ and washed three times with ice-cold PBS by centrifugation at $300 \mathrm{~g}$ for $7 \mathrm{~min}$ to remove unbound bacteria from the pellet. The cells were suspended in $1 \mathrm{ml}$ of PBS and stored in the dark at $4^{\circ} \mathrm{C}$ until analysed within $24 \mathrm{~h}$ by flow cytometry.

\section{Flow cytometric analysis}

The main cell population was gated by forward and side light scatter to exclude debris and cell aggregates. The percentage of cells with fluorescence greater than the background was determined on a histogram produced by log-amplified red fluorescence signals and mean fluorescence of the positive population on a histogram produced by linear signals. The values were multiplied to obtain a binding index $\left(B_{\text {Ind }}\right)$ for each sample.

\section{Ingestion of bacteria}

To measure the fluorescence from bacteria ingested by cells, fluorescence from extracellular bacteria was quenched in each sample $(1 \mathrm{ml})$ with $20 \mu \mathrm{l}$ of crystal violet (BDH) $0.05 \%$ in $0.15 \mathrm{~N}$ sodium chloride. As the optical density of the soluble dye and its quenching effect increases with time, flow cytometry was performed when the $O D_{595}$ reading of the sample was $500-600$. In this range $>90 \%$ of the EB-labelled bacteria outside the cells were completely quenched. Crystal violet at higher OD values is membrane permeable and can quench intracellular bacteria. The laser power for these samples was adjusted to compensate for the decrease in background autofluorescence of the control samples due to quenching. An ingestion index $\left(I_{\text {Ind }}\right)$ for each sample was calculated by multiplying the percentage of fluorescent cells and the mean fluorescence as described above.

\section{Intracellular survival of bacteria}

Uninfected and RSV-infected THP-1 cells were incubated with live unlabelled bacteria under the above conditions for $30 \mathrm{~min}$. Extracellular bacteria were killed by adding gentamicin $30 \mu \mathrm{g} / \mathrm{ml}$ and ampicillin $50 \mu \mathrm{g} / \mathrm{ml}$ for $15 \mathrm{~min}$ at $37^{\circ} \mathrm{C}$. After three washes with PBS, the cells were resuspended in $100 \mu \mathrm{l}$ of PBS and lysed with an equal volume of sodium lauryl sulphate $0.05 \%$ in sterile distilled water. Samples were immediately plated in triplicate for determination of cfu as described above. For a time course study of intracellular survival and growth of bacteria, cells were incubated for different periods before lysing and plating.

\section{Binding of anti-CD antibodies to cells}

The flow cytometry method described previously to detect host cell antigens on buccal epithelial cells was used in these experiments [26]. Uninfected and RSVinfected THP-1 cells were incubated at $4^{\circ} \mathrm{C}$ for $30 \mathrm{~min}$ with the following mouse MAbs: CD1la (Dako) diluted 1 in 20, CD18 (Dako) diluted 1 in 20, CD15 (Scottish A ntibody Production Unit, Carluke) diluted 1 in 20, CD14 (Dako) diluted 1 in 10 and CD29 (Serotec) diluted 1 in 20. The samples were washed three times with PBS. Fluorescein isothiocyanate (FITC)-labelled anti-mouse immunoglobulin antibody (Sigma) diluted 1 in 100 was used to detect binding of the primary antibodies to cells. The samples were washed three times and fixed with buffered paraformaldehyde (Sigma) $0.5 \%$. Cells with fluorescence greater than the control (cells treated only with the FITC-labelled second antibody) were assessed for mean fluorescence and the binding index was calculated as described above.

\section{TNF - $\alpha$ bioactivity}

Uninfected and RSV-infected THP-1 cells were incubated in $\mathrm{CO}_{2} 5 \%$ at $37^{\circ} \mathrm{C}$ with unlabelled live or EBlabelled fixed bacteria at a ratio of 10 bacteria per cell in 24-well tissue culture plates (Costar). A fter incubation for $24 \mathrm{~h}$, supernates from individual wells were collected for determination of TNF- $\alpha$. A bioassay with L-929 cells (a mouse fibroblast cell line) was used to determine TNF- $\alpha$ activity [27].

\section{Statistical analysis}

Paired $t$ tests were used to analyse data from binding and ingestion of bacteria, and for binding of anti-CD MA bs to uninfected or RSV-infected cells. Wilcoxon's test for matched pairs was applied to the data from experiments measuring intracellular survival of bacteria. The data for TNF- $\alpha$ production by uninfected or RSV-infected THP-1 cells under various conditions were also analysed by paired t tests.

\section{Results}

The proportions of RSV-infected cells were similar with both mouse anti-G MAb and absorbed human convalescent serum. At $24 \mathrm{~h}$ after infection, $40-50 \%$ of THP-1 cells were infected with RSV. RSV infection did not affect the viability of cells $24 \mathrm{~h}$ after infection.

\section{Bacterial binding, ingestion and survival}

Bacteria were able to bind to cells at 0 min (data not shown), but intracellular bacteria were not detected at this time either by quenching the external bacteria or by determination of intracellular survival. Data from nine experiments on binding of $H$. influenzae, $M$. catarrhalis and pneumococci are presented in Fig. 1 and on ingestion of these bacteria in Fig. 2.

$H$. influenzae. The binding observed for strain $\mathrm{HI} 1$ to 


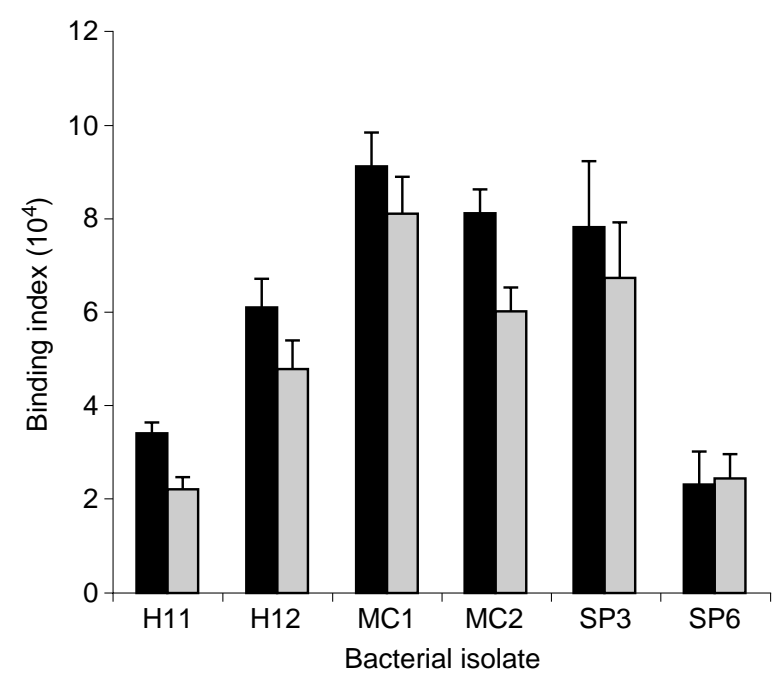

Fig. 1. Binding indices (SE) of $H$. influenzae isolates (HII and HI2), M. catarrhalis isolates (MC1 and MC2) and S. pneumoniae types 3 and type 6 (SP3 and SP6) to THP-1 and RSV-infected THP-1 cells (mean of nine experiments); $\mathbf{\square}$, uninfected THP-1 cells; $\square$, RSVinfected THP-1 cells.

uninfected THP-1 cells was $50 \%$ of that observed for strain HI2 $(p<0.05)$. Strain HII also bound significantly less to RSV-infected cells than strain $\mathrm{HI} 2$ $(p<0.01)$. Compared with uninfected cells, binding of both the strains to cells infected with RSV was significantly reduced: $\mathrm{HI}, \mathrm{p}<0.01,95 \% \mathrm{Cl}-5520$, $-18141 ; \mathrm{HI}, \mathrm{p}<0.0295 \% \mathrm{Cl}-1588,-25237$. RSV infection of cells reduced the ingestion of both strains, but this was significant only for $\mathrm{HI}(\mathrm{p}<0.05,95 \% \mathrm{Cl}$ $-791,-12793)$. Both the isolates survived better in RSV-infected cells than in uninfected cells $(p<0.02$, HII, $\quad Z=-2.366 ; \quad p<0.05, \quad H I 2, \quad Z=-2.1974)$ (Fig. 3).

M. catarrhalis. Compared with strain $M C 2$, strain MC1 bound in greater numbers to uninfected THP-1 cells $(p<0.001)$ and to RSV-infected cells $(p<0.005)$.
Both strains MC1 and MC2 bound significantly less to RSV-infected cells than to uninfected cells: $M C 1$, $\mathrm{p}<0.01,95 \% \mathrm{Cl}-6796,-11840 ; \mathrm{MC2}, \mathrm{p}<0.002$, $95 \% \mathrm{Cl}-12258,-28233$. RSV infection of cells reduced the ingestion of both strains ( $M C 1, N S$; $M C 2$, $\mathrm{p}<0.05,95 \% \mathrm{Cl}-335,-31328)$. Neither of the isolates survived in uninfected or RSV-infected THP-1 cells in the conditions used in the study.

S. pneumoniae. Compared with strain SP6, strain SP3 bound significantly more to uninfected cells $(p<0.05)$ and to RSV-infected cells $(p<0.05)$. Compared with uninfected cells, lower numbers of strain SP3 bound to RSV-infected cells $(p=0.051,95 \% \mathrm{Cl} 55,-23737)$. There was no significant difference in binding of strain SP6 to uninfected or RSV-infected cells. A decrease in ingestion of strain SP3 by RSV-infected cells was observed $(p=0.059,95 \% \mathrm{Cl} 1212,-45717)$. There was no significant difference for strain SP6 in ingestion by uninfected or RSV-infected THP-1 cells. Significantly greater numbers of strain SP3 survived in RSVinfected cells than in uninfected cells $(p<0.05$, $Z=-2.0226$ ) (Fig. 3). Strain SP6 showed evidence of only occasional survival in uninfected cells, which was twice as high in RSV-infected cells.

\section{Effect of RSV infection on binding of anti-CD MAbs to cells}

$M$ ean $B_{\text {Ind }}$ for the MAbs directed towards the cell surface antigens of THP-1 cells are summarised in Fig. $4 a$ and $b$. In seven experiments, RSV infection resulted in significant decreases in binding of the following MAbs: anti-CD 11a by $35 \%(p<0.05,95 \% \mathrm{Cl}-20$, $-50)$; anti-CD 18 by $24 \%(p<0.001,95 \% \mathrm{Cl}-16$, $-32)$; anti-CD 14 by $28 \%(p<0.05,95 \% \mathrm{Cl}-3,-53)$ and anti-CD 15 by $30 \%(\mathrm{p}<0.05,95 \% \mathrm{Cl}-3,-57)$. There was an increase of $9 \%$ in binding of anti-CD29 to RSV-infected THP-1 cells, but it was not statistically significant.

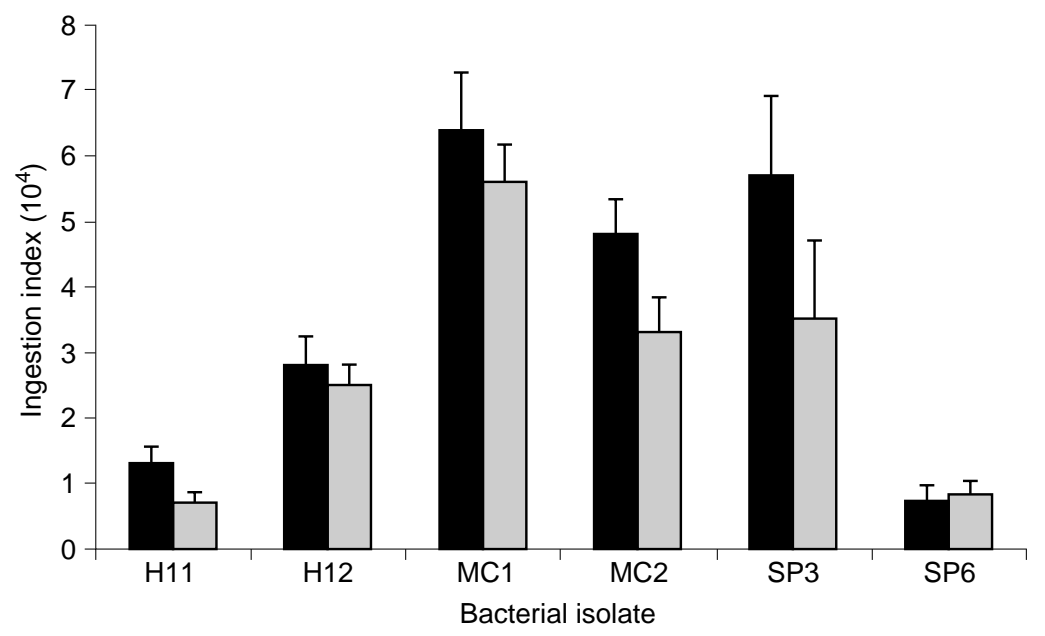

Fig. 2. Ingestion indices (SE) of $H$. influenzae isolates (HI1 and HI2), M. catarrhalis isolates (MC1 and MC2) and S. pneumoniae types 3 and type 6 (SP 3 and SP6) to THP-1 and RSV-infected THP-1 cells (mean of nine experiments); 口, uninfected THP-1 cells; $\square$, RSV-infected THP-1 cells. 


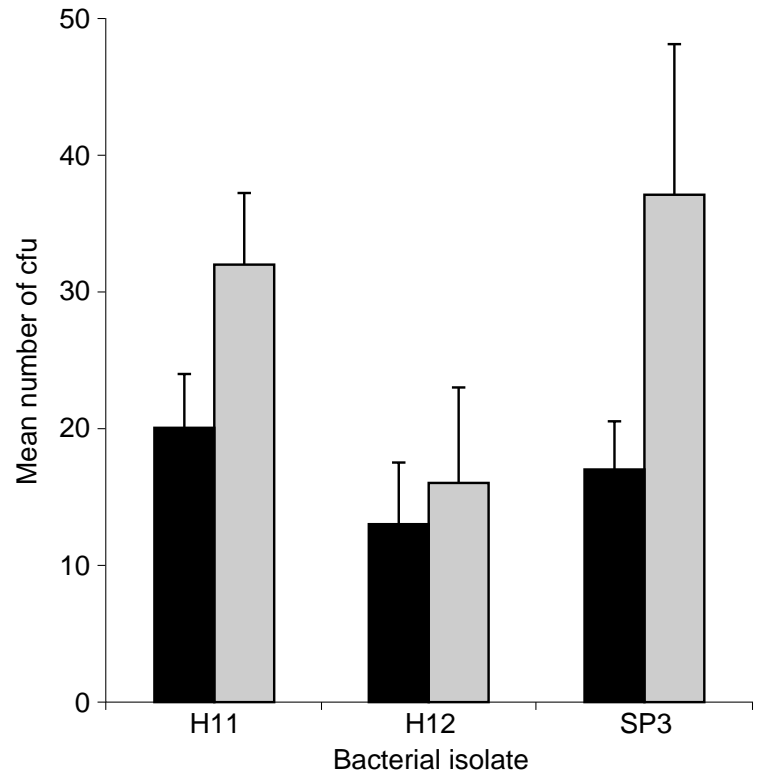

Fig. 3. Survival of $\mathrm{H}$. influenzae isolates (HII and $\mathrm{HI} 2)$ and S. pneumoniae type 3 (SP3) in uninfected and RSVinfected THP-1 cells (mean of seven experiments); uninfected THP-1 cells; $\square$ RSV-infected THP-1 cells.

Effect of RSV infection and bacteria on TNF- $\alpha$ bioactivity of cells

TNF- $\alpha$ bioactivity in supernates of uninfected or RSVinfected THP-1 cells incubated with either live unlabelled or fixed EB-labelled bacteria was determined (Fig. 5). In seven experiments, compared with THP-1 cells to which no bacteria were added, the bioactivity was increased by incubation of THP-1 cells with live strains: HI1, p $<0.01(95 \% \mathrm{Cl} 11.5,45.9)$;
HI2, $p<0.001(95 \%$ Cl 24.3, 50.6); $M C 1, p<0.05$ $(95 \% \mathrm{Cl} 8.5,59.2) ; \mathrm{MC} 2, \mathrm{p}<0.05$ (95\% Cl 5.1, 47.2); $\mathrm{SP} 3, \mathrm{p}<0.001(95 \% \mathrm{Cl} 48.6,65.9)$ or SP6, $\mathrm{p}<0.005$ $(95 \% \mathrm{Cl} 15.5,44.5)$. Differences in the levels of TNF$\alpha$ induced were not statistically significant between strains of the same species.

Compared with THP-1 cells to which no bacteria were added, the TNF- $\alpha$ bioactivity was increased by incubation of THP-1 cells with EB-labelled fixed strains: HI1, $\mathrm{p}<0.05(95 \% \mathrm{Cl} 4.1,31.9) ; \mathrm{HI}$, $\mathrm{p}<0.001(95 \% \mathrm{Cl} 19,42.4) ; \mathrm{MC} 1, \mathrm{p}<0.002(95 \%$ Cl 23.1, 63.2); $M C 2, p<0.001(95 \% \mathrm{Cl} 38.9,59)$; SP3, $p<0.02(95 \% \mathrm{Cl} 5.9,29.5)$ or SP6, NS. Compared with fixed strain $\mathrm{HI}$, fixed strain $\mathrm{HI} 2$ elicited significantly more TNF- $\alpha$ bioactivity $(p<$ $0.005,95 \% \mathrm{Cl} 6,19.3)$. Fixed MC2 and SP3 strains elicited greater TNF- $\alpha$ bioactivity compared with fixed MC1 and SP6 strains, respectively, but the differences were not statistically significant.

RSV infection increased TNF- $\alpha$ bioactivity from THP1 cells incubated with live HII, HI2 or MC2 strains, but the differences were not statistically significant. Compared with uninfected cells, TNF- $\alpha$ bioactivity was decreased for RSV-infected cells incubated with live strain $\mathrm{MCl} 1, \mathrm{p}<0.002(95 \% \mathrm{Cl}-49.3,-18.4) ; \mathrm{SP3}$, $\mathrm{p}<0.001(95 \% \mathrm{Cl}-47.6,-20.4)$ or SP6, $\mathrm{p}<0.005$ $(95 \% \mathrm{Cl}-23.2,-8.2)$.

RSV infection increased TNF- $\alpha$ bioactivity from THP1 cells incubated with fixed HII or HI2 strains, but the differences were not statistically significant. Compared with uninfected cells, there was decreased TNF- $\alpha$
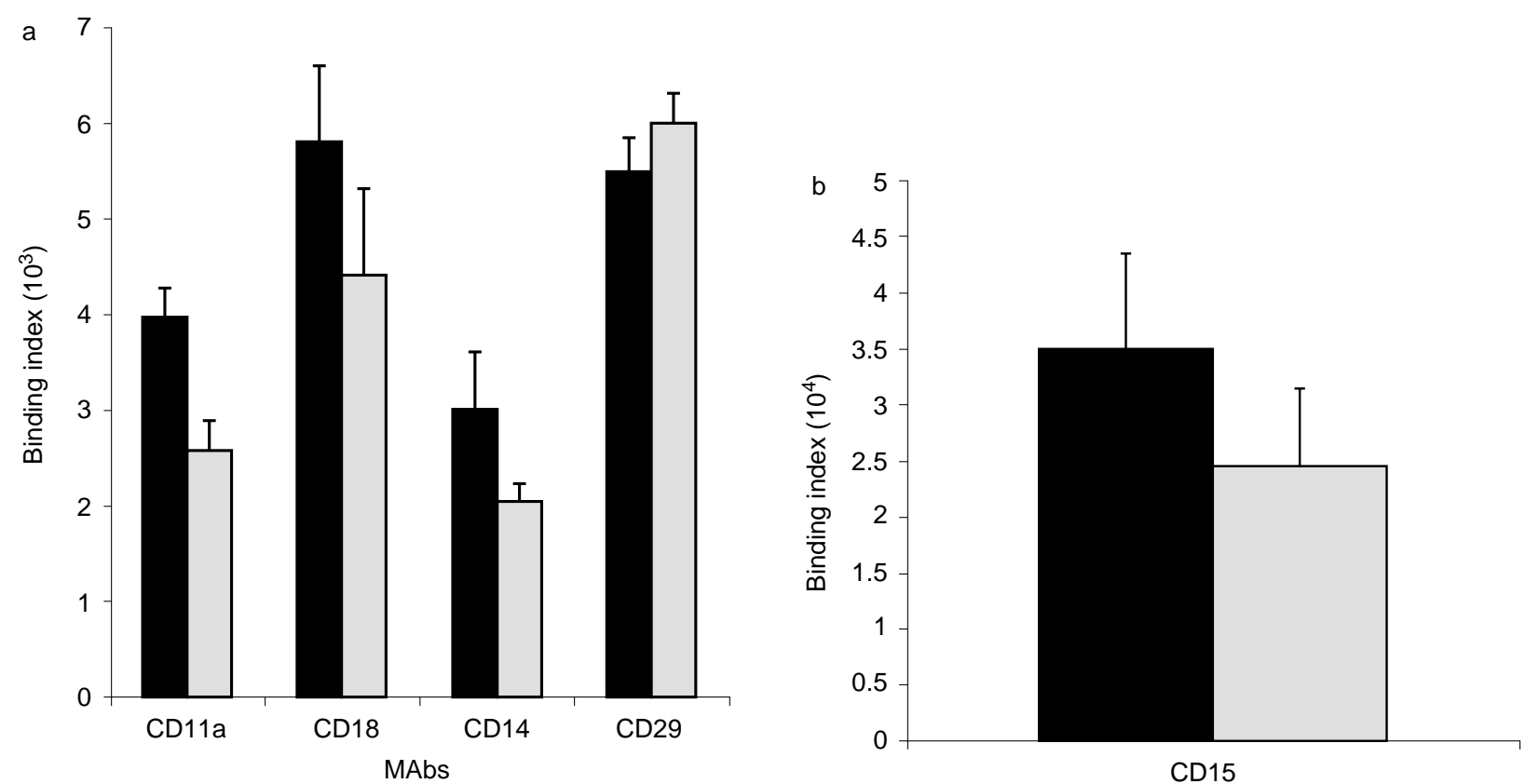

Fig. 4. (a) Binding of MAbs to CD11a, CD18, CD14 and CD29 to uninfected ( $\square$ ) and RSV-infected ( $\square$ ) THP-1 cells (mean of seven experiments). (b) Binding of MAb to CD 15 to uninfected ( $\square$ ) and RSV-infected ( $\square$ ) THP-1 cells (mean of seven experiments). 


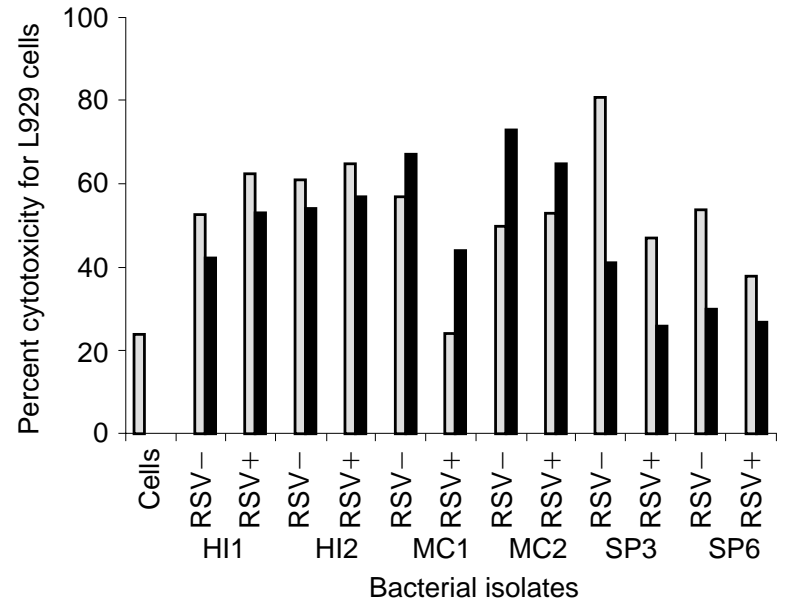

Fig. 5. Percentage cytotoxicity for L-929 cells caused by TNF- $\alpha$ in supernates from uninfected or RSV-infected THP-1 cells incubated with different isolates of live ( $\square$ ) or fixed ( $\boldsymbol{\square})$ bacteria obtained from seven experiments. HI, H. influenzae; M C, M. catarrhalis; SP, S. pneumoniae.

bioactivity with RSV-infected cells incubated with fixed MC1, MC2, SP3 or SP6 strains, but the results were significant only for strain SP3 $(p<0.01,95 \% \mathrm{Cl}$ $-25.5,-5.2)$.

\section{Discussion}

A lthough no significant differences in rates of isolation of bacterial species during exacerbation and stable periods were found in patients with COPD [9], the density of bacterial colonisation of the respiratory tract might contribute to exacerbation. Secondary bacterial infections following virus infections are thought to be associated with enhanced bacterial binding, suppression of host immune responses and bactericidal functions associated with viral infections [28].

Previous studies have shown that RSV infection increases bacterial binding to epithelial cells [10$12,26]$. When infected with RSV, murine alveolar macrophages showed increased cytokine and decreased bactericidal functions [29]. As monocytes play an important role in bactericidal activity in the respiratory tract, the present study used THP-1 cells as a model to examine the effect of RSV infection on binding, ingestion and killing of bacteria.

The bronchial tree has been envisaged as a relatively sterile organ in healthy individuals, in which continuous exposure to inhaled micro-organisms is met with appropriate host defence mechanisms. Heavier growths of bacteria over prolonged periods in the respiratory tract in COPD as a result of inefficient bactericidal mechanisms might cause further damage to the tract due to release of inflammatory cytokines. With this in mind, this study examined the levels of TNF- $\alpha$, a bactericidal agent [22] and a very potent pro- inflammatory cytokine, from THP-1 cells in response to common microbial pathogens.

The first objective was to compare the differences in binding of individual isolates of each bacterial species and their killing by uninfected and RSV-infected THP1 cells. RSV-infected cells demonstrated reduced levels of binding, ingestion and killing of most of the bacteria. The second objective was to assess the effects of RSV infection on surface antigens of the phagocytes that act as receptors for bacteria. Decreased ingestion of most of the bacteria by THP-1 cells infected with RSV might be due to the lower levels of initial bacterial binding observed with these cells. CD14, CD11a, CD18 and CD15 have been identified as receptors for several bacterial species $[16,17]$. Lower levels of these antigens associated with RSV infection might contribute to the decreased bacterial binding observed in this study. However, a correlation test was not performed for BIs of the antibody and bacterial binding to cells, because the two types of experiments were performed on different preparations of cells. Previous studies have demonstrated a significant relationship between bacterial binding and expression of blood group antigens that act as receptors on epithelial cells $[26,30]$.

Increased TNF- $\alpha$ bioactivity contributes to inflammation, whereas a marked decrease can jeopardise mucosal protection against bacteria and bactericidal activity $[31,22]$. The third objective of the present study was to compare TNF- $\alpha$ produced by uninfected and RSV-infected THP-1 cells in response to bacteria. Compared with cells not exposed to bacteria, various degrees of increased responses were observed with all the bacterial isolates. RSV infection reduced TNF- $\alpha$ bioactivity from cells incubated with strains $M C 1, S P 3$ and SP6. RSV infection in human alveolar macrophages can persist for at least 25 days after infection in vitro [32] and in a significant number of patients with COPD [33]. Persistently lower TNF- $\alpha$ responses to the bacteria observed with RSV infection combined with decreased intracellular bactericidal activity might prolong bacterial disease in patients with COPD and cause chronic damage to the respiratory tract.

In conclusion, the differences observed between uninfected and RSV-infected THP-1 cells in the pattern of binding, intracellular killing of bacteria and TNF- $\alpha$ production in response to bacteria may explain the increased susceptibility of virus-infected patients to secondary bacterial infections. Bacteria that escape virus-infected monocytes might have a greater opportunity to grow in the milieu of the respiratory tract and cause disease. Further work to examine the effects of specific antibodies to $S$. pneumoniae on intracellular bacterial survival and production of cytokines from monocytes is under way.

This work was supported by Chest, Heart and Stroke, Scotland. 


\section{References}

1. Silverman EK, Speizer FE. Risk factors for the development of chronic obstructive pulmonary disease. Med Clin North Am 1996; 80: 501- 522.

2. Tager I, Speizer FE. Role of infection in chronic bronchitis. N Engl J Med 1975; 292: 563-571.

3. Murphy TF, Sethi S. Bacterial infection in chronic obstructive pulmonary disease. Am Rev Respir Dis 1992; 146: 1067-1083.

4. Calder MA, Schonell ME. Pneumococcal typing and the problem of endogenous or exogenous reinfection in chronic bronchitis. Lancet 1971; 1: 1156-1159.

5. Smith CB, Kanner RE, Golden CA, Renzetti AD. Haemophilus influenzae and Haemophilus parainfluenzae in chronic obstructive pulmonary disease. Lancet 1976; 1: 1253-1255.

6. Nicotra B, Rivera M, Luman JI, Wallace RJ. Branhamella catarrhalis as a lower respiratory tract pathogen in patients with chronic lung disease. Arch Intern Med 1986; 146: 890-893.

7. Seddon PC, Sunderland D, O'Halloran SM, Hart CA, Heaf DP. Branhamella catarrhalis colonization in preschool asthmatics. Pediatr Pulmonol 1992; 13: 133-135.

8. Hall CB, Walsh EE, Long CE, Schnabel KC. Immunity to and frequency of reinfection with respiratory syncytial virus. J Infect Dis 1991; 163: 693-698.

9. Fagon JY, Chastre J. Severe exacerbations of COPD patients: the role of pulmonary infections. Semin Respir Infect 1996; 11: $109-118$.

10. Raza MW, Ogilvie MM, Blackwell CC, Stewart J, Elton RA, Weir DM. Effect of respiratory syncytial virus infection on binding of Neisseria meningitidis and Haemophilus influenzae type $\mathrm{b}$ to a human epithelial cell line (HEp-2). Epidemiol Infect 1993; 110: 339-347.

11. Elahmer OR, Raza MW, Ogilvie MM, Blackwell CC, Weir $D M$, Elton RA. The effect of respiratory virus infection on expression of cell surface antigens associated with binding of potentially pathogenic bacteria. In: Kahane I, Ofek I (eds) Toward anti-adhesion therapy for microbial diseases. (A dvances in experimental medicine and biology, vol 408.) New York, Plenum. 1996: 169-177.

12. Saadi AT, Blackwell CC, Essery SD et al. Developmental and environmental factors that enhance binding of Bordetella pertussis to human epithelial cells in relation to sudden infant death syndrome (SIDS). FEMS Immunol Med Microbiol 1996; 16: $51-59$.

13. Korppi $M$, Leinonen $M$, Koskela $M, M$ akela $P H$, Launiala $K$. Bacterial coinfection in children hospitalized with respiratory syncytial virus infections. Pediatr Infect Dis J 1989; 8: 687-692.

14. Tsuchiya S, Yamabe $M$, Yamaguchi $Y$, Kobayashi $Y, K$ onno $T$, Tada K. Establishment and characterization of a human acute monocytic leukemia cell line (THP-1). Int J Cancer 1980; 26: $171-176$.

15. Chen F, Kuhn DC, Gaydos LJ, Demers LM. Induction of nitric oxide and nitric oxide synthase mRNA by silica and lipopolysaccharide in PMA-primed THP-1 cells. APMIS 1996; 104: 176- 182.

16. Wright SD, Jong MTC. Adhesion-promoting receptors on human macrophages recognize Escherichia coli by binding to lipopolysaccharide. J Exp Med 1986; 164: 1876-1888.
17. Rozdzinski $E$, Tuomanen $E$. Interactions of bacteria with leukocyte integrins. Methods Enzymol 1994; 236: 333-345.

18. Hynes RO. Integrins: versatility, modulation, and signaling in cell adhesion. Cell 1992; 69: 11-25.

19. Salkind $A R$, Nichols JE, Robert NJ. Suppressed expression of ICAM-1 and LFA-1 and abrogation of leukocyte collaboration after exposure of human mononuclear leukocytes to respiratory syncytial virus in vitro. Comparison with exposure to influenza virus. J Clin Invest 1991; 88: 505-511.

20. Neuzil KM, Tang Y-W, Graham BS. Protective role of TNF- $\alpha$ in respiratory syncytial virus infection in vitro and in vivo. Am J Med Sci 1996; 311: 201-203.

21. Cirino NM, Panuska JR, Villani A et al. Restricted replication of respiratory syncytial virus in human alveolar macrophages. I Gen Virol 1993; 74: 1527-1537.

22. von der Möhlen MAM, van de Poll $T$, Jansen J, Levi $M$, van Deventer SJH. Release of bactericidal/permeability-increasing protein in experimental endotoxemia and clinical sepsis. Role of tumor necrosis factor. J Immunol 1996; 156: 4969-4973.

23. Westendorp RGJ, Langermans JAM, Huizinga TWJ et al. Genetic influence on cytokine production and fatal meningococcal disease. Lancet 1997; 349: 170-173.

24. Keatings VM, Collins PD, Scott DM, Barnes PJ. Differences in interleukin-8 and tumor necrosis factor- $\alpha$ in induced sputum from patients with chronic obstructive pulmonary disease or asthma. Am J Resp Crit Care Med 1996; 153: 530-534.

25. de Godoy I, Donahoe M, Calhoun WJ, M ancino J, Rogers RM . Elevated TNF-alpha production by peripheral blood monocytes of weight-losing COPD patients. Am J Resp Crit Care Med 1996; 153: 633-637.

26. Saadi AT, Blackwell CC, Raza MW et al. Factors enhancing adherence of toxigenic Staphylococcus aureus to epithelial cells and their possible role in sudden infant death syndrome. Epidemiol Infect 1993; 110: 507-517.

27. Delahooke DM, Barclay GR, Poxton IR. Tumor necrosis factor induction by an aqueous phenol-extracted lipopolysaccharide complex from bacteroides species. Infect Immun 1995; 63: $840-846$.

28. de Graaf-M iltenburg LAM, van Vliet KE, Ten Hagen TLM, Verhoef J, Van Strijp JAG. The role of HSV-induced Fc- and $\mathrm{C} 3 \mathrm{~b}(1)$-receptors in bacterial adherence. J Med Microbiol 1994: 40: 48-54.

29. Franke-Ullmann G, Pförtner $C$, Walter $P$ et al. Alteration of pulmonary macrophage function by respiratory syncytial virus infection in vitro. J Immunol 1995; 154: 268-280.

30. Alkout AM, Blackwell CC, Weir DM et al. Isolation of a cell surface component of $\mathrm{Helicobacter}$ pylori that binds $\mathrm{H}$ type 2, Lewis $^{\mathrm{a}}$ and Lewis $^{\mathrm{b}}$ antigens. Gastroenterology 1997; 112: 1179- 1187.

31. Degre M, Bukholm G, Czarniecki CW. In vitro treatment of HEp-2 cells with human tumor necrosis factor-alpha and human interferons reduces invasiveness of Salmonella typhimurium. J Biol Regul Homeost Agents 1989; 3: 1-7.

32. Panuska JR, Cirino NM, Midulla F, Despot JE, M cFadden ER, Huang YT. Productive infection of isolated human alveolar macrophages by respiratory syncytial virus. J Clin Invest 1990; 86: $113-119$.

33. Mikhalchenkova NN, Kniazeva LD, Slepushkin AN. [Respiratory syncytial virus infection in chronic bronchitis patients.] Ter Arkh 1987; 59: 50-52. 